MATTERS ARISING

\section{EULAR recommendations for the management of knee osteoarthritis}

I welcome the publication of the EULAR recommendations for the management of knee osteoarthritis by the EULAR Standing Committee for International Clinical Studies Including Therapeutic Trials (ESCISIT). However, it is out of date and has been superseded by other more up to date publications such as the recommendations for the medical management of osteoarthritis of the hip and knee by the American College of Rheumatology (ACR) Subcommittee on Osteoarthritis Guidelines ${ }^{2}$ and another review of the medical management of osteoarthritis. ${ }^{3}$ The newer COX-1 sparing nonsteroidal anti-inflammatory drugs, rofecoxib and celecoxib are not discussed in the EULAR recommendations, but they have been included in the other reviews. ${ }^{2}{ }^{3}$

My second criticism of the report is that it contains statements such as "SYSADOA.. may possess structure modification properties", which is misleading and may lead to widespread use of these drugs in the absence of good evidence.

Although the Annals of the Rheumatic Diseases is the official EULAR journal, EULAR reports should be peer reviewed before publication. The ACR recommendations for the management of osteoarthritis of the hip and knee were only accepted in a revised format. ${ }^{2}$ Two of the authors of the review in the $\mathrm{BMJ}^{3}$ are also coauthors of the EULAR report.

A S M JAWAD The Royal London Hospital, Bancroft Road, London E1 4DG, UK

1 Pendleton A, Arden N, Dougados M, Doherty M, Bannwarth B, Bijlsma JWJ, et al. EULAR recommendations for the management of knee osteoarthritis: report of a task force of the Standing Committee for International Clinical Studies Including Therapeutic Trials (ESCISIT). Ann Rheum Dis 2000;59:936-44

2 Altman RD, Hochberg MC, Moskowitz RW Schnitzer TJ. Recommendations for the medical management of osteoarthritis of the hip and knee: 2000 update. Arthritis Rheum 2000;43. 1905-15.

3 Walker-Bone K, Javaid K, Arden N, Cooper C. Regular review: medical management of osteoarthritis. BMJ 2000;321:936-40.

\section{Authors' reply}

We thank Dr Jawad for his interest in the EULAR recommendations. ${ }^{1}$ The fact that the literature search ended at December 1998, excluding evidence based discussion of COX-2 inhibitors, is clearly highlighted and discussed in the paper. Unfortunately, a finite end point needs to be set on any thorough evidence based review, and even the ACR document ${ }^{2}$ was of necessity four months out of date by the time it was published. However, the important strengths of the EULAR document compared with the ACR report are:

1 It used a structured evidence based format rather than just consensus statements.
2 It had input from 23 experts from 12 countries, as opposed to four expert Americans.

3 It undertook additional analyses on published trials to calculate effect sizes and numbers needed to treat where sufficient data were available (that is, it provided new data).

4 The search included surgery and treatments such as topical non-steroidal antiinflammatory drugs, which are not licensed in the USA and which were excluded from the ACR paper.

5 It provided data on the "epidemiology" and quality of clinical trials in knee osteoarthritis (OA) and highlighted important questions that (still in 2001) need to be addressed by future research.

Unlike the review by Walker-Bone and three other coauthors from Southampton, ${ }^{3}$ the EULAR report encompassed both medical and surgical treatments, and carefully examined the literature in response to specific clinically relevant questions rather than in an attempt to produce a pragmatic algorithm. We also calculated effect sizes rather than estimates of efficacy, and did not extrapolate treatment data for the knee (the site to which most data relate) to other joint sites. The difference in outcome from these two contrasting approaches is shown, for example, by the recommendation in the $B M \mathcal{F}$ report to consider intra-articular steroid injection only if an effusion is present, whereas the EULAR committee concluded there is no clear evidence to justify a knee effusion as a predictor of response to such treatment.

The qualified statement that "SYSADOAs may possess structure modification properties, but more studies, using standardised methodologies are required" was based on available evidence and made without prejudice. To introduce bias by ignoring published reports on such treatments would indeed be misleading and against all the ethos of evidence based practice.

Although this was a paper that was drafted, edited, and remodified by 21 European experts in OA, the manuscript was peer reviewed by two additional referees after its submission to the Annals.

The committee are delighted with the growing interest in the management of $\mathrm{OA}$ and that three contrasting reviews were published on the topic in 2000. We, of course, realise the current interest in highly selective COX-2 inhibitors. Importantly, however, the three reports fully concur with respect to the important elements of OA management-the non-pharmacological interventions. They also all agree that paracetamol remains the oral analgesic to try first and, if successful, is the preferred long term oral analgesic.

M DOUGADOS Chairperson ESCISIT Task Force, Service de Rhumatologie B, Hopital Cochin,

27 Rue du Faubourg Saint facques, 75014 Paris, France

M DOHERTY

Co-Chairperson ESCISIT Task Force, Academic Rheumatology, Clinical Sciences Building, City Hospital, Nottingham NG5 1PB, UK

1 Pendleton A, Arden N, Dougados M, Doherty M, Bannwarth B, Bijlsma JWJ, et al. EULAR recommendations for the management of knee steoarthritis: report of a task force of the Standing Committee for International Clinical Studies Including Therapeutic Trials
(ESCISIT). Ann Rheum Dis 2000;59:936-44
2 American College of Rheumatology Subcommittee on Osteoarthritis Guidelines. Recommittee on Osteoarthritis Guidelines. Recommendations for the medical management of osteoarthritis of the hip and knee. Arthritis Rheum 2000;43:1905-15.

3 Walker-Bone K, Javaid K, Arden N, Cooper C. Medical management of osteoarthritis. BMJ 2000;321:936-40.

\section{Coffee consumption, RF, and the risk of RA}

We read with interest the paper entitled "Coffee consumption, rheumatoid factor, and the risk of rheumatoid arthritis", ${ }^{1}$ in which an association between coffee consumption and the presence of a positive rheumatoid factor (RF) in healthy subjects was reported. The authors also observed an increased risk of developing seropositive rheumatoid arthritis (RA), particularly in people who were lifelong non-smokers and drinking four cups of coffee or more. Cigarette smoking seemed to be the single most important risk factor for the development of a positive RF in healthy subjects and was strongly associated with coffee consumption. In view of this, however, it seems surprising that there is no additive risk noted for the development of seropositive RA in people who were heavy smokers and also habitual coffee drinkers.

We suggest that the observed risk for developing seropositive RA in people who have never smoked and who consume more than four cups of coffee is possibly confounded by exposure to passive cigarette smoke. For example, coffee in Finland is often consumed in coffee houses, which are prone to be particularly smoky environments, and coffee drinkers are likely to mix with other coffee drinkers, who are statistically more likely to be smokers.

The risk observed for developing seropositive RA in this study is modest for subjects smoking fewer than 14 cigarettes a day (relative risk 1.28, CI 0.63 to 2.57). At face value, it would seem unlikely that passive smoking could play a role in the development of seropositive RA. However, a Chinese study noted that active cigarette smoking was a moderate risk factor for nasopharyngeal cancer (NPC) $(\mathrm{OR}=1.28,95 \% \mathrm{CI} 1.02$ to 1.61$)$. Despite this, it was observed that women who were lifelong non-smokers had a strong and statistically significant positive association between NPC risk and exposure to substantial passive smoke as a child or as an adult. ${ }^{2}$ Interestingly, those with NPC had an increased risk of a family history of NPC compared with controls. Subjects with RA who are lifelong non-smokers would seem to have a greater genetic predisposition to RA, indeed we have found a strikingly high prevalence of a positive family history of RA in a first or second degree relative in these subjects $(54 \%){ }^{3}$ Possibly, in such genetically "predisposed" subjects passive smoke may induce rheumatoid factor production by a mechanism similar to that in people who are active smokers. The presence of a positive $\mathrm{RF}$ in a healthy person is important, as this increases the risk sevenfold for the development of seropositive RA. ${ }^{4}$

A second potential mechanism by which passive smoke inhalation might predispose subjects to RA is by changing the local environment of the nasopharynx. Both the pneumococcus and meningococcus bacteria are carried in the nasopharynx and both invasive pneumococcal and meningococcal disease are seen significantly more often in passive 
smokers. ${ }^{5}{ }^{6}$ It is interesting to note that NPC is associated with the Epstein-Barr virus, ${ }^{7}$ one of a number of viruses which have been implicated in the pathogenesis of RA. ${ }^{8}$ Therefore, passive smoke might potentially predispose subjects to RA as a result of changes within the nasopharynx resulting in antigenic stimulus by a virus that triggers RA.

We agree with the authors that new information is urgently needed about any factor associated with the risk of RA. In view of emerging data highlighting smoking as an important environmental risk factor for the development of seropositive $\mathrm{RA},{ }^{39}$ and also this study by Heliovaara et al, we propose that passive smoking should be considered as a potential candidate factor for the development of RA.

D HUTCHINSON R MOOTS

Rheumatology Department, University Hospital Aintree, Liverpool, UK

1 Heliövaara $\mathrm{M}$, Aho $\mathrm{K}$, Knekt $\mathrm{P}$, Impivaara $\mathrm{O}$, Reunanen A, Aromaa A. Coffee consumption, rheumatoid factor, and the risk of rheumatoid arthritis. Ann Rheum Dis 2000;59:631-5.

2 Yuan JM, Wang XL, Xiang YB, Gao YT, Ross RK, Yu MC. Non-dietary risk factors for nasopharyngeal carcinoma in Shanghai, China. Int J Cancer 2000;85:364-9.

3 Hutchinson D, Shepstone L, Moots R, Lear JT, Lynch MP. Heavy cigarette smoking is strongly ancith rheumatoid arthritis (RA), particularly in patients without a family history of RA. Ann Rheum Dis 2001;60:223-7.

4 Halldorsdottir HD, Jonsson T, Thorsteinsson J, Valdimarsson H. A prospective study on the
Valdorsdottir HD, Jonsson T, Thorsteinsson incidence of rheumatoid arthritis among people with persistent increase of rheumatoid facple with persistent increase of rheuma
tor. Ann Rheum Dis 2000;59:149-51.

5 Nuorti JP, Butler JC, Farley MM, Harrison LH, McGeer A, Kolczak MS, et al. Cigarette smoking and invasive pneumococcal disease. $N$ Eng J Med 2000;342:681-9.

6 Kriz P, Bobak M, Kriz B. Parental smoking, socioeconomic factors, and risk of invasive meningococcal disease in children: a population based case-control study. Arch Dis Child 2000;83:117-21.

7 Klein G. The Epstein-Barr virus and neoplasia. N Engl J Med 1975;293:1353-7.

8 Ollier W. Rheumatoid arthritis and EpsteinBarr virus: a case of living with the enemy? Ann Barr virus: a case of living with
Rheum Dis 2000;59:497-9.

9 Wilson K, Goldsmith CH. Does smoking cause rheumatoid arthritis? J Rheumatol. 1999;26:1-3

\section{Authors' reply}

It is not easy to measure passive smoking. Nevertheless, determinations of serum cotinine and thiocyanate recommended for the detection of indirect exposure to tobacco smoke have been shown to indicate exposures of recent occurrence. ${ }^{12}$

To test the assumption put forward by Drs Hutchinson and Moots we studied coffee consumption for its associations with serum cotinine and thiocyanate concentrations in a sample of men who had participated in the Mini-Finland Health Survey and served as an age matched control group in a nested case-control study of lung cancer. ${ }^{3}$ A modification of the Nicotine Metabolite RIA kit method (Diagnostic Products Corporation, Los Angeles, USA) was used to determine serum cotinine concentrations. ${ }^{4}$ Serum thiocyanate was determined by the spectrophotometric ferric nitrate method. ${ }^{5}$ Of the total of 158 men in the sample, 39 reported current smoking, and 10 others had serum cotinine $\geqslant 200 \mathrm{mg} / 1$ or thiocyanate $\geqslant 20 \mathrm{nmol} / 1$, suggesting direct exposure to tobacco. Exclusion of these men left 109 non-smokers for the final analyses.
No significant association was seen between the number of daily cups of coffee and serum cotinine concentration (age adjusted $r=0.08, \mathrm{p}=0.38$ ). Contrary to the assumption of Drs Hutchinson and Moots, there was a negative correlation between serum thiocyanate level and coffee consumption (age adjusted $r=-0.21, \mathrm{p}=0.03$ ). The findings are in agreement with our impression that in Finland coffee is not consumed to any greater extent in notably smoky environments. Rather, coffee consumption is confined to breakfast at home and coffee breaks both during working hours and leisure time.

On the basis of these preliminary results it seems unlikely that passive smoking would have correlated strongly enough with coffee consumption to explain the close associations between coffee consumption and the occurrence of rheumatoid factor (RF) and the risk of rheumatoid arthritis (RA) in our study. Nevertheless, our results are far from being conclusive. Whatever the links between coffee consumption, RF, and RA, we agree with Drs Hutchinson and Moots that passive smoking should be considered a potential risk factor for RA.

\section{HELIÖVAARA K AHO P KNEKT \\ A REUNANEN A AROMAA National Public Health Institute, Helsinki, Finland \\ O IMPIVAARA \\ Social Insurance Institution, Research and Development Centre, Turku, Finland}

Correspondence to: Dr M Heliövaara, National Public Health Institute, Mannerheimintie 166, FIN-00300 Helsinki, Finland

markku.heliovaara@ktl.fi

1 Tunstall-Pedoe H, Woodward M, Brown CA. Tea drinking, passive smoking, smoking deception and serum cotinine in the Scottish heart health study. J Clin Epidemiol 1991;44:141114.

2 Husgafvel-Pursiainen K, Sorsa M, Engström K, Einistö P. Passive smoking at work: biochemical and biological measures of exposure to environmental tobacco smoke. Int Arch Occup Environ Health 1987;59:337-45.

3 Knekt P, Raitasalo R, Heliövaara M, Lehtinen V, Pukkala E, Teppo L, et al. Elevated lung cancer risk among persons with depressed mood. Am J Epidemiol 1996;144:1096-103.

4 Perkins SL, Livesey JF, Escares EA, Belcher JM, Dudley DK. High-performance liquidDudley DK. High-performance liquid-
chromatographic method compared with a modified radioimmunoassay of cotinine in plasma. Clin Chem 1991;37:1989-93.

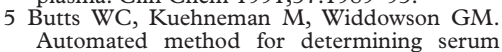
Automated method for determining serum
thiocyanate, to distinguish smokers from nonthiocyanate, to distinguish smokers from
smokers. Clin Chem 1974;20:1344-8.

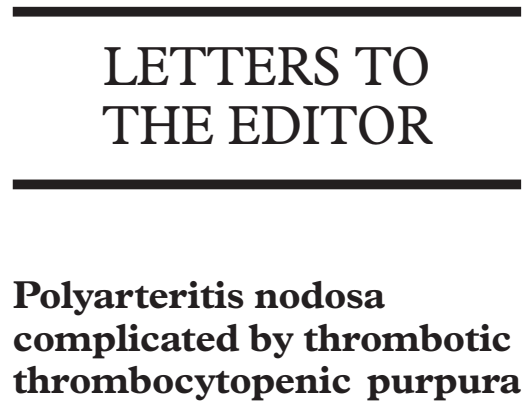

A 56 year old woman was diagnosed with polyarteritis nodosa (PAN) in June 1998 based on the presence of fibrinoid necrosis and infiltration of polymorphonuclear cells into medium and small sized arteries on a skin biopsy specimen. She presented with erythema on her arms and legs, with fever and body weight loss. Tender masses were palpable on her right abdomen. Small erythematous lesions and livedo reticularis were seen on the arms and legs.

Laboratory investigation on admission disclosed anaemia (haemoglobin $73 \mathrm{~g} / \mathrm{l}$ ) and leucocytosis $\left(22.5 \times 10^{9} / 1\right)$ consisting mainly of neutrophils $(85 \%)$. Creatinine clearance was $39 \mathrm{ml} / \mathrm{min}$. Serological examination showed raised levels of $\mathrm{C}$ reactive protein $(88.6 \mathrm{mg} / \mathrm{l})$. Serological tests for syphilis, hepatitis B virus antigen, and antibody for hepatitis $\mathrm{C}$ virus were negative. A high titre of myeloperoxidase antineutrophil cytoplasmic antibody (MPO-ANCA) (201 EU) was detected in her sera. An abdominal computed tomography scan showed bilateral perirenal haemorrhages.

The patient was treated with $1000 \mathrm{mg}$ of methylprednisolone for three successive days, followed by $500 \mathrm{mg}$ cyclophosphamide intravenously. Plasma exchange was performed, also. Within three days, treatment had reduced the body temperature to normal and lowered the $\mathrm{C}$ reactive protein concentration $(<10 \mathrm{mg} / \mathrm{l})$.

The patient rapidly developed thrombocytopenia on the fifth day after admission to hospital, and the lowest platelet count was $15.0 \times 10^{9} / 1$ on the eighth day after admission. She became unconscious, and showed features of haemolytic anaemia and renal failure. A provisional diagnosis of disseminated intravascular coagulation was made because of thrombocytopenia, a low concentration of fibrinogen (1.6 g/l), and a high fibrinogen and fibrin degradation product level $(22.6 \mu \mathrm{g} / \mathrm{ml})$. We treated her with nafamostat mesilate $(200 \mathrm{mg} /$ day) and infusion of fresh-frozen plasma. This treatment produced a marked increase in fibrinogen concentration but failed to improve the platelet count. Further laboratory tests showed fragmented red blood cells in peripheral blood. A diagnosis of thrombotic thrombocytopenic purpura (TTP) was established based on these findings. The patient was treated with plasma exchange with $2700 \mathrm{ml}$ fresh-frozen plasma.

Within one week of treatment the platelet count returned to normal and consciousness level improved dramatically. However, renal failure was irreversible and she continued to undergo dialysis. Unfortunately, the patient died from haemorrhage from a duodenal ulcer. Necropsy findings included small and medium sized polyarteritis in the kidney, uterus, pulmonary hilum, hepatic hilum,

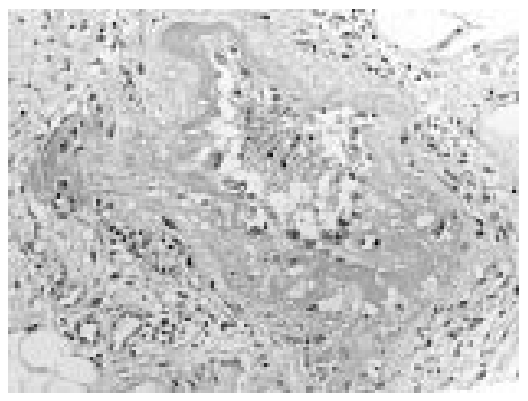

Figure 1 Necropsy finding of ileum end. Note fibrinoid necrosis of medium sized artery. Haematoxylin and eosin stain. Magnification $\times 400$. 
adrenal grand, ileum (fig 1), and ascending colon. Several stages of vasculitis existed, which was a typical finding of classic PAN. We failed to detect vasculitis affecting arterioles, venules, or capillaries. Duodenal bleeding was from peptic ulcers, which is not associated with arteritis.

A few reports have described TTP complicating certain forms of rheumatic diseases, including systemic lupus erythematosus and systemic sclerosis. ${ }^{12}$ To our knowledge there are no reports published in English of PAN complicated by TTP.

The necropsy finding was classic PAN because vasculitis affected vessels larger than arterioles and there were no pathological findings of glomerulonephritis. ${ }^{3}$ We failed to detect vasculitis affecting arterioles, venules, or capillaries. MPO-ANCA is usually a marker of microscopic polyarteritis or necrotising glomerulonephritis but does not distinguish it from classic PAN with certainty.

Our case suggests the possibility of secondary TTP due to PAN. We speculate that endothelium damage by PAN may enhance the development of TTP, particularly in the presence of inflammatory processes. Our patient unfortunately died from massive bleeding from a duodenal ulcer. However, conventional treatment for TTP, including plasma infusion and plasma exchange, were effective in this case, too. ${ }^{5}$ Our case emphasises the need to consider TTP when thrombocytopenia occurs with vascular disease, because early and correct treatment of TTP may improve morbidity and mortality in these patients.

S YAMASAKI M TOMINAGA

A KAWAKAMI

K MIGITA

Y KAWABE

K IZUMINO

K EGUCHI

First Department of Internal Medicine, Nagasaki University School of Medicine, Nagasaki, fapan

T TSUCHIYA I SHIMOKAWA First Department of Pathology, Nagasaki University School of Medicine

Correspondence to: Dr K Eguchi, First Department of Internal Medicine, Nagasaki University School of Medicine, Sakamoto 1-7-1, Nagasaki 852-8501, Japan

eguchi@net.nagasaki-u.ac.jp

1 Fox DA, Faix JD, Coblyn J, Fraser P, Smith B Weinblatt ME. Thrombotic thrombocytopenic purpura and systemic lupus erythematosus. Ann Rheum Dis 1986;45:319-22 .

2 Miller A, Ryan PFJ, Dowling JP. Vasculitis and thrombotic thrombocytopenic purpura in patient with limited scleroderma. J Rheumatol 1997;4:598-600.

3 Jannette JC, Falk RJ, Andrassy K, Bacon PA, Churg J, Gross WL, et al. Nomenclature of systemic vasculitis: proposal of an international consensus conference. Arthritis Rheum 1994; 37:187-92.

4 Guillevin L, Lhote F. Polyarteritis nodosa and microscopic polyangitis. Clin Exp Immunol 1995;101(suppl 1):22-3.

5 Rock GA, Shumak KH, Buskard NA, Blanchette VS, Kelton JG, Spasoff RA, et al. Comparison of plasma exchange with plasma infusion in the treatment of thrombotic thrombocytopenic purpura. N Engl J Med 1991;325: 393-7.

\section{Placement of intra-articular injections verified by ultrasonography and injected air as contrast medium}

Intra-articular injection of long acting corticosteroid is a corner stone in rheumatological treatment. The injected intra-articular corticoid is more effective when correctly placed. ${ }^{12}$ Injection of radiographic contrast material has shown that fewer than half of the injections are correctly placed in the joint space after blind injection.

Generally, the clinical application of ultrasonographic examinations can be enhanced by contrast agents. ${ }^{3}$ The most commonly used technique is creation of microbubble contrast agents. Such agents, applied to the bloodstream, have been used for hepatic, nephrologic, cardiologic, and transcranial examinations. ${ }^{4}$ Obviously, the risk of air embolism depends on the anatomical site of the injected air contrast. Transient ischaemic attacks are described after echocardiography with air contrast ${ }^{5}$ and in animal models haemodynamic effects during venous air infusion can be measured. ${ }^{6}$ Intra-articular injection of air and subsequent lateral and posterior radiographs have shown that this technique can enhance the precision of the procedure. ${ }^{7}$ The disadvantage of this method is that the result can first be seen after the injection, and that a correction can only be made with a new injection. In the joint space the air is separated from the vascular system and when only small amounts of sterile air are used the risk of venous air embolism is negligible. Air is a very effective contrast medium in ultrasonography. Air sonography has been used for the diagnosis of meniscus lesions in knee joints ${ }^{8}$ and for rotator cuff lesions in the shoulder'.

We expand the applicability of this method to all joints, not only for diagnosis, but also for the correct placement of the needle before injection of medicine (steroid, osmium acid, viscosupplementation). The sterile air that is contained in the capped vial with lidocain or steroid is used as contrast medium. The needle is guided into the joint space of the distended capsule by ultrasonography.

When the steroid and lidocain are mixed in the syringe a small volume of air will be in the needle itself $(\sim 0.05 \mathrm{ml})$. The air in the needle is clearly seen when the injection is started and will secure the correct placement of the needle. With this technique, it is not necessary to use two separate syringes and the inclination of the syringe will not cause the air to move from the needle to the bottom of the syringe.

If the knee is injected, injection directly into the recess of the knee is recommended, which will make the small volume of air momentarily visible.

Figure 1 illustrates the ultrasonography of a metatarsophalangeal joint in a patient before and after injected air. The intraarticular air is clearly seen. We have made over 1000 ultrasonography guided intraarticular injections without any complications. This method is easy, inexpensive, without risk and radiation, and should be used routinely in rheumatology. Chemical synovectomy of the knee, especially, should always be guided by ultrasonography, and with this technique smaller joins can also be considered for chemical synovectomy.

\section{U FREDBERG}

Medical Department (Rheumatology), Silkeborg Centralhospital, DK-8600 Silkeborg, Denmark

G VAN OVEREEM HANSEN Department of Rheumatology, Kong Chr X's Gigthospital Graasten, DK-6300 Graasten, Denmark

L BOLVIG

Department of Radiology, University Hospital of Aarhus, DK-8000 Aarhus C, Denmark

Correspondence to: Dr U Fredberg, Ostermarksvej 29, DK-8381 Tilst, Denmark

Fredberg@post4.tele.dk

1 Eustace JA, Brophy DP, Gibney RP, Bresnihan B, FitzGerald O. Comparison of the accuracy of steroid placement with clinical outcome in patients with shoulder symptoms. Ann Rheum Dis 1997;56:59-63.

2 Zingas C, Failla JM, Van Holsbeeck $M$. Injection accuracy and clinical relief of de Quervain's tendinitis. J Hand Surg [Am] 1998; 23:89-96.

3 Campani R, Calliada F, Bottinelli O, Bozzini A, Sommaruga MG, Draghi F, et al. Contrast enhancing agents in ultrasonography: clinical applications. Eur J Radiol 1998; 27(suppl 2):161-70

Widder DJ, Simeone JF. Microbubbles as a contrast agent for neurosonography and ultrasound. AJR Am J Roentgenol 1986;147:34752.

5 Srivastava TN, Undesser EK. Transient ischemic attack after air contrast echocardiog396.

6 Vik A, Jenssen BM, Brubakk AO. Comparison of haemodynamic effects during venous air infusion in pigs. Eur J Appl Physiol. 1994;68: infusion $127-33$.

7 Bliddal H. Placement of intra-articular injections verified by mini air-arthrography. Ann Rheum Dis 1999;58:641-3.

8 Hawe W, Milz P. The clinical value of air sonography in the diagnosis of meniscus lesions. A prospective study of 50 knee joints. Sportverletz Sportschaden 1991;5:119-26.

9 Hawe W. Air as contrast medium in sonography of the rotator cuff (aero-sonographic diagnosis). Rontgenpraxis 1991;44:75-8.

\section{HLA class II alleles and synovial fluid cytology in RA}

Rheumatoid arthritis (RA) is associated with HLA-DR4, which is encoded by the DRB1 gene. This genetic predisposition has been shown to lie within the sequence motif present in the third hypervariable region of the DRB1 gene. ${ }^{1}$ This sequence of amino acids has been called the "disease epitope" and can be encoded by DR4 subtypes as well as non-DR4 alleles; DR1 subtypes, DR10 and DR14 subtypes . ${ }^{1}$ Hence, it is also termed the shared epitope. In addition to imparting susceptibility to RA, HLA-DR4 has also been shown to be associated with the severity of the rheumatoid disease, including destructive erosive joint disease, rheumatoid factor positivity, ${ }^{2}$ and extra-articular manifestations, such as rheumatoid nodules, vasculitis, and Felty's syndrome. ${ }^{3}$ HLA-DQ genes are in linkage disequilibrium with HLA-DR and subjects who are DR4 positive may either be DQB $1{ }^{\star} 0301$ or ${ }^{\star} 0302$ positive; certain extraarticular features of RA have been shown to be associated with HLA-DQB1 ${ }^{\star} 0301 .{ }^{45}$

Synovial fluid cytology in RA is heterogeneous both with respect to total white cell 
count and to the proportions of polymorphs, leucocytes containing intracytoplasmic granules and have been shown to be present in higher percentages in the joints of patients with RA. ${ }^{6}$ Davis et al showed that when a patient with RA has a relapse affecting the same joint, the proportions of cell types remain similar, though the total white cell count may differ. ${ }^{7}$ The same study also found a significantly poorer outcome in patients with persistently high ragocyte counts as assessed by the necessity for subsequent joint replacement or synovectomy. lymphocytes, and ragocytes. ${ }^{6}$ Ragocytes are

As both synovial cytology and genetic factors have been shown independently to predict joint damage, this study aimed at assessing whether there is a relation between genetic factors and the pattern of synovial fluid cytology which might also be of prognostic significance.

Fifty nine unrelated patients with RA attending the Department of Rheumatology, Hope Hospital, Salford, were studied. All the patients were white and had classic or definite RA according to the 1987 American Rheumatism Association Criteria. ${ }^{8}$ All had synovial fluid analysed on at least one occasion

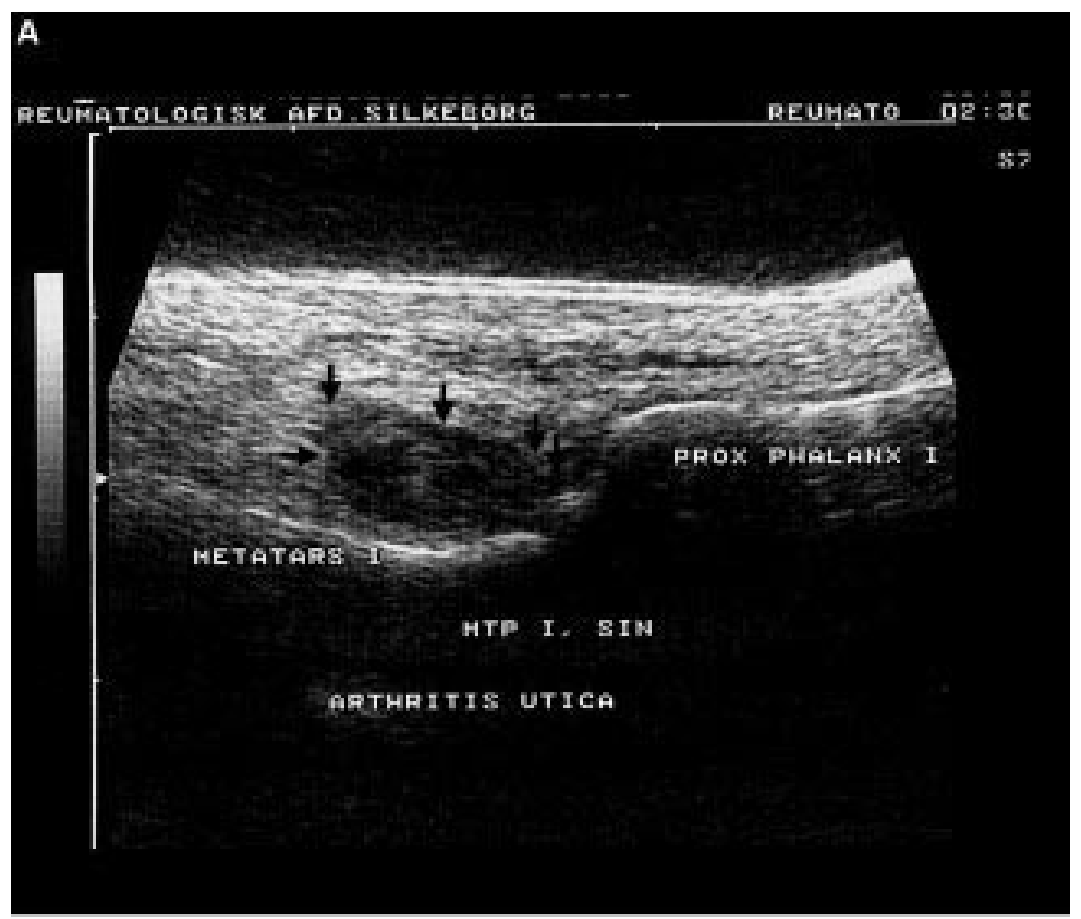

B
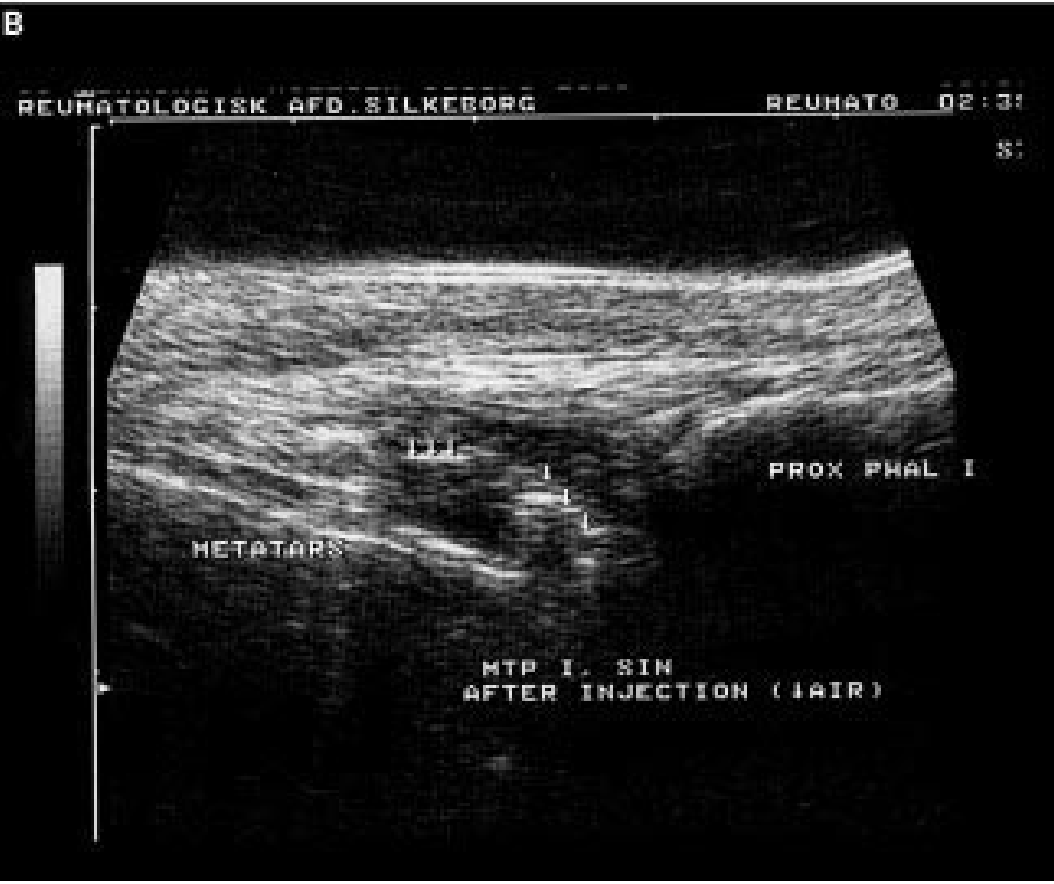

Figure 1 (A) Ultrasonography of a metatarsophalangeal (MTP) joint before injection. The distended capsule is seen (black arrows). (B) Ultrasonography of MTP joint after injection of sterile air (white arrows) and $2 \mathrm{ml}$ steroid. Only the volume of air that is in the needle itself is injected $(\sim 0.05 \mathrm{ml})$. during articular flares of arthritis. Blood was taken for HLA typing from each patient. Clinical details recorded were age, sex, disease duration, and drug treatment.

All synovial fluid samples collected were placed in $2 \mathrm{ml}$ paediatric lithium heparin bottles and processed the same day. Total white cell count was carried out with a modified Fusch Rosenthal counting chamber and expressed as cells $/ \mathrm{cm}^{3}$. Polymorphs, lymphocytes, monocytes, and ragocytes ${ }^{6}$ were differentiated in a cytocentrifuged and wet preparation using simple morphology and expressed as percentages of all nucleated cells. Genomic DNA was extracted as described previously. ${ }^{9}$ DRB, DQA and B were typed by polymerase chain reaction, followed by hybridisation to specific oligonucleotide probes. ${ }^{3}$ Rheumatoid factor was measured by the sheep cell agglutination test and titres $\geqslant 1 / 32$ were considered positive. Data for white blood cells, polymorphs, lymphocytes, ragocytes, and monocytes were not normally distributed and were expressed as medians (interquartile range). The MannWhitney U test was used to compare these variables between the different patient groups. When more than two groups were compared the Kruskal-Wallis one way analysis of variance was used. Corrections for multiple comparisons were also made.

The 59 patients ( 45 female, 14 male) had a median age of 63 years (range 27-85) and median duration of disease of 16.5 years (range 2-53). Of these 59 patients, 55 were seropositive for rheumatoid factor, 52 had erosive disease, 27 had extra-articular features (nodules, Felty's syndrome, Sjögren's syndrome, vasculitis, peripheral neuropathy, pulmonary, renal disease, and/or eye disease), and 43 were receiving a disease modifying antirheumatic drug (DMARD) with or without oral steroids at the time of the study.

HLA-DR typing showed that 44 (75\%) patients were DR4 positive. Eight (18\%) of the DR4 positive patients were compound heterozygotes (DRB $\left.1^{\star} 0401 / 0404\right)$. Forty five $(76 \%)$ patients were "RA epitope" positive (DR4/DRB1 *0401, DR4/DRB1 *0404, DR4/ $\mathrm{DRB} 1{ }^{\star} 0405$, or DR1) and $24(41 \%)$ were heterozygous for the "RA epitope". HLA-DQ typing showed that $25(42 \%)$ patients were positive for DQB $1{ }^{\star} 0301$.

When the patients were subdivided into those who were positive or negative for HLADR4, there were no differences in the total white cell count or proportion of the cell types between the two groups, and these were also similar between patients who were or were not compound heterozygotes.

However, when the patients were subdivided into those who were epitope positive or negative, there was an increased median percentage lymphocyte count in patients who were positive (median 11\%) compared with those who were negative (median 3\%, $\left.\mathrm{p}=0.036, \mathrm{p}_{\text {corr }}>0.05\right)$. There were no differences in the other cell type counts between the two groups.

When the patients were subdivided into those who were positive or negative for HLADQB $1^{\star} 0301$, patients who were positive for the allele $(n=25)$ had an increased median percentage ragocyte count $(50 \%)$ compared with those who were negative $(n=20,10 \%$, $\left.\mathrm{p}=0.033, \mathrm{p}_{\text {corr }}>0.05\right)$. The percentages of the other cell types were similar in the two groups. When the HLA-DR4 status was also taken into account, there was a higher median percentage of white cells typed as ragocytes $(57.5 \%)$ in $\mathrm{DR} 4+/ \mathrm{DQB} 1^{\star} 0301+$ patients 
Table 1 Synovial fluid cytology in patients with rheumatoid arthritis subdivided into different HLA-DR4 and/or DQB1*0301 groups

\begin{tabular}{|c|c|c|c|c|c|}
\hline Patients $n=$ numbers & $\begin{array}{l}\text { White blood } \\
\text { cells }\left(\mathrm{cm}^{3}\right)\end{array}$ & $\begin{array}{l}\text { Ragocytes } \\
(\%)\end{array}$ & $\begin{array}{l}\text { Polymorphs } \\
(\%)\end{array}$ & $\begin{array}{l}\text { Lymphocytes } \\
(\%)\end{array}$ & $\begin{array}{l}\text { Monocytes } \\
(\%)\end{array}$ \\
\hline \multicolumn{6}{|l|}{ a. $\mathrm{DQB} 1{ }^{\star} 0301+(\mathrm{n}=25)$} \\
\hline Median & 8.74 & 50 & 73 & 6 & 2 \\
\hline Interquartile range & $3.6-16.5$ & $2.5-80$ & $0-87.5$ & $0-19.5$ & $0-8$ \\
\hline \multicolumn{6}{|l|}{ b. DQB $1^{\star} 0301-(\mathrm{n}=20)$} \\
\hline Median & 5.75 & 10 & 64 & 15.5 & 6.5 \\
\hline Interquartile range & $2.9-12.0$ & $0-40$ & $9.3-85.8$ & $3.25-37.8$ & $1.3-13.3$ \\
\hline Comparing a with $\mathrm{b}$ ( $\mathrm{p}$ value) & 0.3 & $0.033^{\star}$ & 0.78 & 0.11 & 0.10 \\
\hline \multicolumn{6}{|l|}{ c. $\mathrm{DR} 4+/ \mathrm{DQB} 1{ }^{\star} 0301+(\mathrm{n}=20)$} \\
\hline Median & 8.5 & 57.5 & 71.5 & 4 & 1.5 \\
\hline Interquartile range & $3.7-18.1$ & $10-85$ & $0-86$ & $0-19.5$ & $0-6$ \\
\hline \multicolumn{6}{|l|}{ d. DR4-/DQB $1^{\star} 0301-(n=6)$} \\
\hline Median & 6.7 & 27.5 & 70.5 & 3.5 & 3.5 \\
\hline Interquartile range & $0.3-10.9$ & $0-40$ & $0-79$ & $0-12$ & $0-6.5$ \\
\hline Comparing $\mathrm{c}$ with $\mathrm{d}$ ( $\mathrm{p}$ value) & 0.66 & 0.27 & 0.98 & 1.00 & 0.84 \\
\hline \multicolumn{6}{|c|}{ e. $\mathrm{DR} 4+/ \mathrm{DQB} 1{ }^{\star} 0301-(\mathrm{n}=14)$} \\
\hline Median & 5.8 & 3.8 & 59 & 22.5 & 8.5 \\
\hline Interquartile range & $3.3-9.2$ & $0-30$ & $13.5-83$ & $4.5-40$ & $3-14.5$ \\
\hline Comparing $\mathrm{c}$ with $\mathrm{e}$ ( $\mathrm{p}$ value) & 0.34 & $0.017^{\star}$ & 0.99 & $0.02^{\star}$ & $0.027^{\star}$ \\
\hline \multicolumn{6}{|l|}{ f. DR4-/DQB1*0310+ (n=5) } \\
\hline Median & 9.2 & 5 & 74 & 12 & 4 \\
\hline Interquartile range & $3.6-13.9$ & $0-52.5$ & $21-84.5$ & $3.75-16.5$ & $1-7$ \\
\hline Comparing $\mathrm{d}$ with $\mathrm{f}$ ( $\mathrm{p}$ value) & 0.66 & 0.93 & 0.66 & 0.43 & 0.66 \\
\hline
\end{tabular}

^Significant on Mann-Whitney $U$ test uncorrected, $\mathrm{p}_{\text {corr }}>0.05$ for all four $\mathrm{p}$ values.

$(\mathrm{n}=20)$ than in those who were DR4+/ DQB $1^{\star} 0301-(3.8 \%, \quad \mathrm{n}=14, \quad \mathrm{p}=0.017$ $\left.\mathrm{p}_{\text {corr }}>0.05\right)$. The $\mathrm{DR} 4+/ \mathrm{DQB} 1^{\star} 0301+$ group also had a reduced median lymphocyte percentage (4\%) and monocyte count $(1.5 \%)$ in comparison with $\mathrm{DR} 4+/ \mathrm{DQB} 1^{\star} 0301-$ patients $(22.5 \%, \mathrm{p}=0.02,8.5 \%, \mathrm{p}=0.027$, $\left.\mathrm{p}_{\text {corr }}>0.05\right)$. Table 1 summarises these results.

There were no statistical differences in synovial fluid cytology depending on whether the patients were positive or negative for rheumatoid factor, those with erosive or nonerosive disease, presence or absence of extraarticular features, and treatment with or without DMARDs and/or steroids.

Even though the corrected $\mathrm{p}$ values were not significant, this study suggests that there is a genetic influence on the expression of synovial fluid cytology in patients with RA. The presence of HLA-DR4 together with DQB $1^{\star} 0301$ leads to an increase in ragocyte cells in the synovial fluid and a reduced lymphocyte and monocyte count. We speculate that the increase in activity of joint disease, and hence severity of the disease, might be due to the presence of excess ragocytes in the synovial fluid or to the loss of dampening effect owing to the reduced number of lymphocytes/monocytes. Ragocytes are leucocytes with intracytoplasmic granules and their function is unknown. ${ }^{7}$ In contrast, there was an increase in the percentage of lymphocytes in the synovial fluid of patients who were positive for the rheumatoid epitope Once again the type of lymphocytes was unknown, but we can speculate that the presence of HLA-DR1 must have been the influencing allele because there were no significant differences in the cell counts when patients who were positive or negative for HLA-DR4 were compared.

The patients in this study were a selected group as they were hospital attenders with joint effusions requiring aspirations and thus had more severe disease than patients without joint effusions who could be managed as outpatients. In this selected group we found no association between synovial fluid cytology and the presence or absence of rheumatoid factor or extra-articular features, erosive or non-erosive disease, and the treatment with DMARDs and/or steroids. This is perhaps expected as patients with negative rheumatoid factor can develop severe joint disease. Although the presence of extra-articular features contributes to the overall morbidity of RA, it is not always associated with severe articular disease. Finally, our treatment of patients with DMARDs with and without steroids does not depend on the severity of articular disease alone and is based on the overall activity of the rheumatoid disease. On the other hand, treatment with DMARDs and steroids may modify synovial fluid findings, but we cannot draw any conclusions from this study as it is a cross sectional study and previous treatment was not taken into account.

Thus we have shown that synovial fluid cytology is influenced by genetic factors, but larger studies are needed to confirm these results. Further studies at the molecular level will help to determine the exact mechanism of action by which the presence or absence of certain cell types has an effect on the joint pathology of patients with RA. These studies may throw light on the pathogenesis of the joint disease in these patients.

L-S TEH

KM MOUSSA

P A SANDERS

Department of Rheumatology,

University Hospital of South Manchester,

Manchester

J MORRIS

Department of Medical Statistics,

University Hospital of South Manchester

M C HILLARBY

A J FREEMONT
J DENTON

Musculoskeletal Research Group, Stopford Building,

University of Manchester, Manchester

Correspondence to: Dr L-S Teh, Department of Rheumatology, Ward 13, Level 5, Blackburn Royal Infirmary, Blackburn BB2 3LR, UK

1steh@btinternet.com

1 Reveille JD. The genetic contribution to the pathogenesis of rheumatoid arthritis. Curr pathogenesis of rheumatoid arthris

2 Jaraquemada D, Ollier W, Awad J, Young A, Silman A, Roitt IM, et al. HLA and rheumatoid man A, Roitt IM, et al. HLA and rheumatoid
arthritis: a combined analysis of 440 British arthritis: a combined analysis of 440 Britis
patients. Ann Rheum Dis 1986;45:627-36.

patients. Ann Rheum Dis 1986;45:627-36.
3 Hillarby MC, Clarkson R, Grennan DM, Bate AS, Ollier W, Sanders PA, et al. Immunogenetic heterogeneity in rheumatoid disease as illustrated by different $M H C$ associations (DQ, Dw and C4) in articular and extraarticular subsets. Br J Rheumatol 1991;30:5-9.

4 McMahon MJ, Hillarby MC, Clarkson RW, Hollis S, Grennan DM. Major histocompatibility complex variants and articular disease severity in rheumatoid arthritis. Br J Rheumatol 1993;32:899-902.

5 Sansom DM, Amin SN, Bidwell JL, Klouda PT, Bradley BA, Evison G, et al. HLA-DQ-related restriction fragment length polymorphisms in rheumatoid arthritis: evidence for a link with disease expression. Br J Rheumatol 1989;28: 374-8.

6 Hollander JE, McCarty DJ, Astorga G, CastioMurillo E. Studies on the pathogenesis of rheumatoid joint inflammation. 1. The 'RA cell' and a working hypothesis. Ann Intern Med 1965;62:271-80.

7 Davis MJ, Denton J, Freemont AJ, Holt PJL. Comparison of serial synovial fluid cytology in rheumatoid arthritis: delineation of subgroups with prognostic implications. Ann Rheum Dis 1988;47:559-62.

8 Arnett FC, Edworthy SM, Bloch DA, McShane DJ, Fries JF, Cooper NS, et al. The American Rheumatism Association 1987 revised criteria for the classification of rheumatoid arthritis. Arthritis Rheum 1988;31:315-24.

9 Kunkel LM, Smith KD, Boyer SH, Borgaonkar DS, Wachtel SS, Miller OJ, et al. Analysis of DS, Wachtel SS, Miller OJ, et al. Analysis of
human Y-chromosome-specific reiterated DNA in chromosome variants. Proc Natl Acad Sci USA 1977;74:1245-9. 